\title{
Prevalence and antimicrobial resistance of Campylobacter jejuni and Campylobacter coli isolated from children and environmental sources in urban and suburban areas
}

\author{
Bernadeta Szczepanska*, Małgorzata Andrzejewska, Dorota Spica and Jacek J. Klawe
}

\begin{abstract}
Background: Campylobacteriosis is a dominant bacterial cause of foodborne infection and is considered the main public health problem in Europe and many other countries worldwide. In the study lasting from 2011 to 2013 we compared the prevalence and antimicrobial resistance of Campylobacter jejuni and Campylobacter coli isolated from children, domestic animals, poultry meat and surface water in Northern Poland.

Results: During a 3-years study 1973 samples were analysed. The results proved the presence of Campylobacter spp. in 306 (15.5\%) samples. The percentage of Campylobacter-positive samples differed among the sample types, from 0\% (freshwater beaches) to 38.6\% (poultry meat in 2011). Prevalence of Campylobacter spp. in children isolates was 9.6\%. It decreased from 13.2\% in 2011 to 8.0\% in 2013. It should be highlighted with a particular concern that Campylobacter jejuni was detected in $20.0 \%$ of fountains. All children and poultry meat isolates were susceptible to azithromycin. Two C. coli (3.7\%) and four C. jejuni (3.3\%) isolated from poultry meat were resistant to erythromycin. The highest percentage of $C$. jejuni isolates with resistance to ciprofloxacin were found in samples from $80 \%$ dogs and $85 \%$ ponds. Among isolates resistant to two antimicrobials $74.7 \%$ C. jejuni and $59.2 \%$ C. coli isolates were resistant to ciprofloxacin as well as to tetracycline. Only one cat $C$. coli isolate was resistant to both azithromycin and erythromycin. One C. jejuni isolate from a fountain was resistant to four antimicrobial agents (erythromycin, azithromycin, tetracycline and ciprofloxacin).

Conclusions: The study proved that surface water, poultry meat and pets constituted potential sources of Campylobacter to children. Fountains can be a direct source of children campylobacteriosis but can also pollute other environments with multidrug-resistant Campylobacter. The high resistance to some antimicrobials among the isolates may lead to increasing numbers of difficult-to-treat campylobacteriosis cases among children.
\end{abstract}

Keywords: Campylobacter, Children, Pets, Poultry meat, Surface water, Fountains, Antimicrobial resistance

\footnotetext{
*Correspondence: b.szczepanska@cm.umk.pl

Department of Hygiene, Epidemiology and Ergonomics, Nicolaus Copernicus

University in Torun, Collegium Medicum in Bydgoszcz, 9 Sklodowska-Curie

Str, 85-094 Bydgoszcz, PL, Poland
}

\section{$\int$ Biomed Central}

(c) The Author(s). 2017 Open Access This article is distributed under the terms of the Creative Commons Attribution 4.0 International License (http://creativecommons.org/licenses/by/4.0/), which permits unrestricted use, distribution, and reproduction in any medium, provided you give appropriate credit to the original author(s) and the source, provide a link to the Creative Commons license, and indicate if changes were made. The Creative Commons Public Domain Dedication waiver (http://creativecommons.org/publicdomain/zero/1.0/) applies to the data made available in this article, unless otherwise stated. 


\section{Background}

Campylobacteriosis is a dominant bacterial cause of foodborne infection and is considered the main public health problem in Europe and many other countries worldwide [1, 2]. The natural reservoirs of Campylobacter spp. are intestinal tracts of domesticated and wild birds and mammals. Eating or handling with raw or undercooked meat, especially poultry, is considered to be major risk factors for human campylobacteriosis. Other sources of Campylobacter are the following: contaminated drinking water and dairy products, for example unpasteurised milk, swimming in natural water sources and contact with pets [2-4]. Foreign travel may also be a risk factor for Campylobacter infection, especially in small children previously unexposed to exotic or antibiotic-resistant strains present in contaminated meat or water $[5,6]$.

In humans, Campylobacter jejuni and Campylobacter coli are pathogens, routinely causing acute diarrhoea, but sometimes Guillain-Barré syndrome, reactive arthritis and postinfectious polyneuropathy leading to paralysis may occur $[7,8]$.

As a generally self-limiting disease Campylobacter infection does not require therapeutic intervention. In children with fever, increasing bloody diarrhoea or symptoms lasting longer than 1 week and in those who are immunologically compromised antimicrobial treatment should be considered. The drugs of choice used in the clinical therapy of campylobacteriosis are macrolides, such as azithromycin and erythromycin, and fluoroquinolones, such as ciprofloxacin; the first ones are considered to be safe therapeutic agents for children, while the second ones are used occasionally in paediatric patients. Tetracyclines could be considered as an alternative choice in the therapy of Campylobacter infection, but in practice they are not often used [7, 9-11]. According to the results of numerous studies a significant rise in resistance to fluoroquinolones, tetracycline, and erythromycin has been demonstrated in C.jejuni and $C$. coli isolates from various sources such as humans, animals and food [12-15]. What should be stressed is that the number of studies with regard to isolates from surface water is limited.

Studies in many countries have shown that natural environment, like soil and water, is essential in transmission of Campylobacter, either directly to humans or indirectly through farm animals or pets $[5,6,16]$. One of the pathways for spreading of Campylobacter are faeces of wild and domestic animals present in recreational and drinking water. Children can be in contact with animal excrement in the environment during outdoor activities on children's playgrounds or in parks.

The subject of the study was to compare the prevalence and antimicrobial resistance of $C$. jejuni and $C$. coli isolated from children, domestic animals, poultry meat and surface water in urban and suburban areas of the Bydgoszcz region in Poland. The role of environmental exposures in the epidemiology of Campylobacter infection in children under 4 years of age was also analysed.

\section{Methods \\ Sample collection}

Stool samples from 1030 children aged 0-4 with diarrhoea were obtained from the Infectious Diseases Hospital in Bydgoszcz, Northern Poland. We examined 433 samples of poultry meat from randomly selected supermarkets and butcher shops in the study region. Among the said samples there were chicken filets, chicken wings, chicken leg quarters, chicken drumsticks, turkey filets. Rectal swabs were collected from 260 pets (146 dogs and 114 cats). The samples were taken from young animals aged from 2 weeks to 24 months, living with their owners, in shelters, as well as from veterinary clinics during routine check-ups. The animals had no signs of gastrointestinal disease. A total of 250 surface water samples (from ponds and ornamental lakes, freshwater beaches, Brda and Vistula rivers and city fountains) were examined in the study. Table 1 presents all samples collected and tested over a period of 3 years from 2011 to 2013.

\section{Isolation of Campylobacter spp.}

Isolation of Campylobacter spp. from stool samples was performed according to the World Health Organization recommendations [17], with the use of Charcoal Cefoperazone Deoxycholate Agar (CCDA) (Oxoid, Basingstoke, United Kingdom). Plates were incubated at $42{ }^{\circ} \mathrm{C}$ for $48 \mathrm{~h}$ in a microaerobic atmosphere generated by a Generbox microaer (BioMerieux, Marcy l'Etoile, France). Isolation of Campylobacter spp. from poultry meat was conducted in compliance with the EN ISO 10272-1:2006 method [18]. Twenty five grams of meat were placed into $225 \mathrm{ml}$ of Bolton broth (Oxoid) containing the Bolton broth selective supplement (Oxoid) and 5\% laked horse blood (Oxoid). Next, bacterial suspension was spread onto CCDA plates, and then incubated at $42{ }^{\circ} \mathrm{C}$ for $48 \mathrm{~h}$ under microaerobic conditions. Isolation from water samples was performed in accordance with the recommendations of the Health Protection Agency [19]. Water samples were filtered through a $0.45 \mu \mathrm{m}$ filter (Millipore 0.45) and the filter was then transferred to $100 \mathrm{ml}$ of Bolton broth containing the Bolton broth selective supplement (Oxoid). The broths were incubated at $42{ }^{\circ} \mathrm{C}$ in a microaerobic atmosphere for $48 \mathrm{~h}$ and then streaked on CCDA plates. Rectal swabs from domestic animals were stored at $4{ }^{\circ} \mathrm{C}$ in a transport medium Amies Agar Gel - With Charcoal (Copan Italia, Brescia, Italy), transmitted onto the Bolton broth containing the Bolton broth selective supplement (Oxoid), and then incubated under the conditions described above. 
Table 1 Prevalence of Campylobacter isolated from different sources in Poland from 2011 to 2013

\begin{tabular}{|c|c|c|c|c|c|}
\hline \multirow[t]{2}{*}{ Sample type } & \multirow[t]{2}{*}{ Year/sample type } & \multirow{2}{*}{$\begin{array}{l}\text { No. of samples } \\
\text { tested }\end{array}$} & \multirow{2}{*}{$\begin{array}{l}\text { No. (\%) of samples positive } \\
\text { for Campylobacter }\end{array}$} & \multicolumn{2}{|c|}{ No. (\%) of samples positive for } \\
\hline & & & & C. jejuni & C. coli \\
\hline \multirow[t]{4}{*}{ Children } & 2011 & 264 & $35(13.3)$ & $32(12.1)$ & $3(1.1)$ \\
\hline & 2012 & 393 & $34(8.7)$ & $32(8.1)$ & $2(0.5)$ \\
\hline & 2013 & 373 & $30(8.0)$ & $28(7.5)$ & $2(0.5)$ \\
\hline & Total & 1030 & $99(9.6)$ & $92(8.9)$ & $7(0.7)$ \\
\hline \multirow[t]{4}{*}{ Poultry meat } & 2011 & 140 & $54(38.6)$ & $29(20.7)$ & $25(17.9)$ \\
\hline & 2012 & 143 & $42(29.4)$ & $31(21.7)$ & $11(7.7)$ \\
\hline & 2013 & 150 & $48(32.0)$ & $30(20.0)$ & $18(12.0)$ \\
\hline & Total & 433 & $144(33.3)$ & $90(20.8)$ & $54(12.5)$ \\
\hline \multirow[t]{3}{*}{ Pets } & dogs & 146 & $9(6.2)$ & $5(3.4)$ & $4(2.7)$ \\
\hline & cats & 114 & $12(10.5)$ & $10(8.8)$ & $2(1.8)$ \\
\hline & Total & 260 & $21(8.1)$ & $15(5.8)$ & $6(2.3)$ \\
\hline \multirow[t]{5}{*}{ Surface water } & Rivers & 40 & $7(17.5)$ & $5(12.5)$ & $2(5.0)$ \\
\hline & Ponds and ornamental lakes & 150 & $30(20.0)$ & $20(13.3)$ & $10(6.7)$ \\
\hline & Freshwater beaches & 35 & 0 & 0 & 0 \\
\hline & Fountains & 25 & $5(20.0)$ & $5(20.0)$ & 0 \\
\hline & Total & 250 & $42(16.8)$ & $30(12.0)$ & $12(4.8)$ \\
\hline Total & & 1973 & $306(15.5)$ & $227(11.5)$ & $79(4.0)$ \\
\hline
\end{tabular}

Broth cultures were streaked onto CCDA plates and incubated at $42{ }^{\circ} \mathrm{C}$ under microaerobic conditions for $48 \mathrm{~h}$. Characteristic growth from CCDA plates for all types of samples was placed on a blood plate (Columbia agar with 5\% sheep blood) (Oxoid) and incubated overnight at $42{ }^{\circ} \mathrm{C}$. Suspected colonies were confirmed as Campylobacter on the base of cell morphology by the Gram staining method and motility. An oxidase test was performed using Oxidase Identification Sticks (Oxoid) in compliance with the manufacturer's instructions. The hippurate hydrolysis test with a 3.5\% ninhydrin solution was used to identify C. jejuni isolates [17]. Subsequently, two suspected colonies per sample were selected and streaked on Columbia agar containing 5\% sheep blood (Oxoid) and incubated at $37{ }^{\circ} \mathrm{C}$ for $48 \mathrm{~h}$ under microaerobic conditions. All confirmed and purified Campylobacter isolates were stored in the archive at $-80{ }^{\circ} \mathrm{C}$ in Microbanks (Pro-Lab Diagnostics, United Kingdom).

\section{DNA extraction}

Genomic DNAs were obtained from 24-h cultures on Columbia agar containing $5 \%$ sheep blood by a conventional boiling method [20]. Bacterial colonies were suspended in $100 \mu \mathrm{l}$ PBS with $45 \mu \mathrm{l}$ Chelex 100 chelating resin (BioRad, USA) and next boiled for $10 \mathrm{~min}$. The samples were cooled on ice and centrifuged at 13,000 $\mathrm{x} g$ for $10 \mathrm{~min}$. The supernatant was stored at $-20^{\circ} \mathrm{C}$. Aliquots of $1 \mu \mathrm{l}$ of template DNA were used for PCR.

\section{Identification of Campylobacter spp.}

The PCR method with specific primers as described by On and Jordan was used for the purpose of identification of colonies as C. jejuni or C. coli $[21,22]$. The primers for C.jejuni were C. jejuni Random (5'-CA TCT TCC CTA GTC AAG CCT-3') [22], resulting in an amplicon of $773 \mathrm{bp}$, and the primers for $C$. coli were C. coli Random (5'-AG GCA AGG GAG CCT TTA ATC-3') [22], resulting in an amplicon of 364 bp. PCR reactions were performed in final mixture volume of $25 \mu \mathrm{l}$ containing $1.0 \mu \mathrm{l}$ of each PCR primer $(10 \mu \mathrm{M})$ (Oligo, Warsaw, Poland), $2.5 \mu \mathrm{l}$ of $10 \times$ PCR buffer (Fermentas, Vilnius, Lithuania), $1.0 \mu \mathrm{l}$ of $10 \mathrm{mM}$ deoxynucleoside triphosphate mix (Fermentas), $2.5 \mu \mathrm{l}$ of $25 \mathrm{mM} \mathrm{MgCl}_{2}$ (Fermentas), $0.5 \mu \mathrm{l}$ of Dream Taq DNA Polymerase $(1 \mathrm{U} / \mu \mathrm{l})$ (Fermentas), $1.0 \mu \mathrm{l}$ of template and $13.0 \mu \mathrm{l}$ of DNA-free purified water (Fermentas) [23]. DNA amplification was carried by an initial denaturation step at $94{ }^{\circ} \mathrm{C}$ for $5 \mathrm{~min}$, then 30 cycles of $94{ }^{\circ} \mathrm{C}$ for $30 \mathrm{~s}, 61{ }^{\circ} \mathrm{C}$ for $30 \mathrm{~s}$ and $72{ }^{\circ} \mathrm{C}$ for $30 \mathrm{~s}$ in a Bio-Rad thermocycler. The final extension was performed at $72{ }^{\circ} \mathrm{C}$ for $5 \mathrm{~min}$. The amplified DNAs were analysed by electrophoresis in a 1.5\% agarose gel. Gels were visualised by staining them with the Midori Green Stain (Nippon Genetics, Duren, Germany) and photographed by using the IG/L-E InGenius L documentation system (Syngene, Cambridge, United Kingdom). A 100 bp DNA marker (Fermentas) was used as a size marker for the PCR amplicons. 


\section{Antimicrobial susceptibility testing}

The susceptibility of $C$. jejuni and C. coli to antibiotics was determined with the E-test (AB Biodisk, Solna, Sweden) on Mueller-Hinton agar with $5 \%$ defibrinated horse blood (bioMerieux, Marcy l'Etoile, France) and in compliance with the manufacturer's instructions [24]. Azithromycin, erythromycin, gentamicin, ciprofloxacin and tetracycline - five antimicrobials clinically used and most often tested in both food/animal and human isolates were analysed. The plates were incubated at $37{ }^{\circ} \mathrm{C}$ for $48 \mathrm{~h}$ under microaerobic conditions. The breakpoints for Campylobacter resistance were interpreted by means of criteria for the Enterobacteriaceae family according to Clinical and Laboratory Standards Institute [25]: azithromycin, $8 \mu \mathrm{g} / \mathrm{mL}$; erythromycin, $32 \mu \mathrm{g} / \mathrm{mL}$; gentamicin, $8 \mu \mathrm{g} / \mathrm{mL}$ tetracycline, $16 \mu \mathrm{g} / \mathrm{mL}$ and ciprofloxacin, $4 \mu \mathrm{g} / \mathrm{mL}$. C. jejuni ATCC 33560, C. jejuni ATCC 33291 and C.coli ATCC 33559 were used as control strains.

\section{Statistical analysis}

Statistical calculations were performed by means of the Statistica 10.0 program (StatSoft Poland, 2011). The association between the prevalence of Campylobacter spp. in individual sample types and antimicrobial resistance between $C$. jejuni and $C$. coli were analysed with a two-proportion test. $P$ values of $<0.05$ were considered statistically significant.

\section{Results}

\section{Prevalence of Campylobacter spp. in various sources}

During our 3-years study 1973 samples from children, domestic animals, poultry meat and surface water were analysed (Table 1). The results have indicated the presence of Campylobacter spp. in 306 (15.5\%) of the samples. Frequency of $C$. jejuni in the examined samples was $11.5 \%$. C. coli was found in $4.0 \%$ of the analysed samples. The two-proportion test revealed that $C$. jejuni isolates were significantly more frequently detected than $C$. coli isolates in all types of the examined samples $(p<0.5)$. The samples from poultry meat had the highest prevalence of Campylobacter (33.3\% in 3 years). The proportion of Campylobacter-positive samples varied among various sample types, from 0\% (freshwater beaches) to $38.6 \%$ (poultry meat in 2011). The prevalence of Campylobacter spp. in children isolates was $9.6 \%$. It decreased from $13.2 \%$ in 2011 to $8.0 \%$ in 2013 ( $p=0.0323)$. Campylobacter spp. was detected in $20.0 \%$ of fountains and in all cases it was identified as C. jejuni. Over the course of our research, the lowest prevalence of the examined bacteria was observed in $8.1 \%$ pets, in particular dogs (6.2\%). Statistical hypotheses were tested between two sources. Sources were taken in various combinations into each hypothesis. From this point of view there were statistically significant differences between the prevalence of Campylobacter in various sources, with the exception of the prevalence in isolates from children and pets (children vs. pets, $p>0.05$ ).

\section{Antimicrobial resistance}

The lowest antimicrobial resistance rate were noted for gentamicin and azithromycin (Table 2). All isolates from children and poultry meat were susceptible to azithromycin. One $C$. jejuni and one $C$. coli isolates from cats, and three $C$. jejuni isolates from surface water (from ponds and fountains) were resistant to azithromycin. Resistance to erythromycin was detected in two C. coli (3.7\%) and four C. jejuni (3.3\%) isolated from poultry meat. High rates of ciprofloxacin resistance $(>50 \%)$ were noted in all isolates. In particular higher level of resistance to fluoroquinolones was found within the $C$. coli isolated from children and from poultry meat $(71.4$ and $74.1 \%$, respectively) rather than within $C$. jejuni (65.2 and $62.2 \%$, respectively); however, this difference was not statistically significant. The highest percentage of $C$. jejuni isolates resistant to ciprofloxacin was found in samples obtained from $4 / 5$ dogs (80\%) and $17 / 20$ ponds (85\%). The lower level of resistance was observed in relation to tetracycline.

Table 3 shows antimicrobial resistance phenotype patterns among tested Campylobacter. Resistance to two or more antimicrobials was found in $40 \%$ of $C$. jejuni and $29 \%$ of C. coli isolates in all types of samples. Among isolates resistant to two antimicrobials $74.7 \%$ C.jejuni and $59.2 \%$ C. coli isolates combined resistance to ciprofloxacin and tetracycline. In comparison to C. coli isolates, C. jejuni isolates were more often resistant to three or more antimicrobials (2.5\% vs. $5.7 \%)$. Combination of ciprofloxacin, tetracycline and erythromycin resistance, found in C. jejuni isolates from poultry meat and water was observed most frequently within the group resistant to three or more antibiotics. Only one $C$. coli isolate from cats was resistant to both erythromycin and azithromycin. The study revealed that one C.jejuni isolate from a fountain was resistant to four antimicrobial agents (erythromycin, azithromycin, tetracycline and ciprofloxacin).

\section{Discussion}

Bydgoszcz is a city in northern Poland, on the Brda and Vistula rivers and the Bydgoszcz Canal, with an urban agglomeration with more than 470,000 inhabitants. About $35 \%$ of the city's area is covered with parks and recreational areas with numerous ponds and fountains. We were interested in the influence of these environment agents on campylobacteriosis in young children (0-4). In several studies, this age group was indicated as a group of high risk of campylobacteriosis [26-28]. It can be a result of not fully established immune response, as well as deficient hand hygiene and contact with animals and the environment. In our study we emphasized specific environmental urban and 
Table 2 Campylobacter isolates susceptibility to antibiotics ${ }^{\mathrm{a}}$

\begin{tabular}{|c|c|c|c|c|c|c|c|c|c|c|}
\hline \multirow{3}{*}{$\begin{array}{l}\text { Antimicrobial } \\
\text { agent }\end{array}$} & \multirow{3}{*}{$\begin{array}{l}\text { Campylobacter } \\
\text { species }\end{array}$} & \multicolumn{9}{|c|}{ No. (\%) of resistant isolates } \\
\hline & & \multirow[t]{2}{*}{ Children } & \multirow{2}{*}{$\begin{array}{l}\text { Poultry } \\
\text { meat }\end{array}$} & \multicolumn{3}{|c|}{ Domestic animals } & \multicolumn{4}{|c|}{ Surface water } \\
\hline & & & & Total & Dogs & Cats & Total & Rivers & $\begin{array}{l}\text { Ponds and } \\
\text { ornamental lakes }\end{array}$ & Fountains \\
\hline \multirow[t]{2}{*}{ Erythromycin } & C. coli & $0 / 7$ & 2/54 (3.7) & $1 / 6(16.7)$ & $0 / 4$ & $1 / 2(50.0)$ & $0 / 12$ & $0 / 2$ & 0/10 & 0 \\
\hline & C. jejuni & 0/92 & 4/90 (4.4) & $0 / 15$ & $0 / 5$ & $0 / 10$ & $3 / 30(10.0)$ & $0 / 5$ & $1 / 20(5.0)$ & $2 / 5(40.0)$ \\
\hline \multirow[t]{2}{*}{ Azithromycin } & C. coli & $0 / 7$ & $0 / 54$ & $1 / 6(16.7)$ & $0 / 4$ & $1 / 2(50.0)$ & $0 / 12$ & $0 / 2$ & 0/10 & 0 \\
\hline & C. jejuni & 0/92 & $0 / 90$ & $1 / 15(6.7)$ & $0 / 5$ & $1 / 10(10.0)$ & $3 / 30(10.0)$ & $0 / 5$ & $1 / 20(5.0)$ & $2 / 5(40.0)$ \\
\hline \multirow[t]{2}{*}{ Gentamicin } & C. coli & $0 / 7$ & $0 / 54$ & $0 / 6$ & $0 / 4$ & $0 / 2$ & $0 / 12$ & $0 / 2$ & 0/10 & 0 \\
\hline & C. jejuni & 1/92 (1.1) & $1 / 90(1.0)$ & $0 / 15$ & $0 / 5$ & $0 / 10$ & $0 / 30$ & $0 / 5$ & $0 / 20$ & $0 / 5$ \\
\hline \multirow[t]{2}{*}{ Tetracycline } & C. coli & 3/7 (42.9) & $17 / 54(31.5)$ & $3 / 6(50.0)$ & 2/4 (50.0) & $1 / 2(50.0)$ & $6 / 12(50.0)$ & $1 / 2(50.0)$ & $5 / 10(50.0)$ & 0 \\
\hline & C. jejuni & 36/92 (39.1) & 46/90 (51.1) & 5/15 (33.3) & $2 / 5(40.0)$ & $3 / 10(30.0)$ & 18/30 (60.0) & $2 / 5(40.0)$ & $13 / 20(65.0)$ & $3 / 5(60.0)$ \\
\hline \multirow[t]{2}{*}{ Ciprofloxacin } & C. coli & $5 / 7(71.4)$ & 40/54 (74.1) & $3 / 6(50.0)$ & $2 / 4(50.0)$ & $1 / 2(50.0)$ & $8 / 12(66.7)$ & $1 / 2(50.0)$ & 7/10 (70.0) & 0 \\
\hline & C. jejuni & 60/92 (65.2) & $56 / 90(62.2)$ & $9 / 15(60.0)$ & $4 / 5(80.0)$ & $5 / 10(50.0)$ & $24 / 30(80.0)$ & $3 / 5(60.0)$ & 17/20 (85.0) & $4 / 5(80.0)$ \\
\hline
\end{tabular}

${ }^{\mathrm{a}}$ Results expressed as the number of resistant isolates vs. total number of isolates analyzed

Table 3 Antimicrobial resistance phenotype patterns among the tested Campylobacter (results expressed as the number of resistant isolates vs. total number of isolates analyzed)

\begin{tabular}{|c|c|c|c|c|c|}
\hline \multirow{2}{*}{$\begin{array}{l}\text { Antimicrobial resistance } \\
\text { phenotype }\end{array}$} & \multirow{2}{*}{$\begin{array}{l}\text { Campylobacter } \\
\text { species }\end{array}$} & \multicolumn{4}{|c|}{ No. (\%) of resistant isolates } \\
\hline & & Children & Poultry meat & Pets & Surface water \\
\hline \multirow[t]{2}{*}{ Sensitive for all } & C. coli & $1 / 7(14.3)$ & $8 / 54(14.8)$ & 2/6 (33.3) & $2 / 12(16.7)$ \\
\hline & C. jejuni & 14/92 (15.2) & 10/90 (11.1) & $4 / 15(26.7)$ & $5 / 30(16.7)$ \\
\hline \multirow[t]{2}{*}{$A Z M+E M$} & C. coli & $0 / 7$ & $0 / 54$ & $1 / 6(16.7)$ & $0 / 12$ \\
\hline & C. jejuni & 0/92 & $0 / 90$ & $0 / 15$ & $2 / 30(6.7)$ \\
\hline \multirow[t]{2}{*}{$\mathrm{TC}+\mathrm{Cl}$} & C. coli & 2/7 (28.6) & 10/54 (18.5) & 2/6 (33.3) & $2 / 12(16.7)$ \\
\hline & C. jejuni & 34/92 (37.0) & $12 / 90(13.3)$ & $4 / 15(26.7)$ & $9 / 30(30.0)$ \\
\hline \multirow[t]{2}{*}{$T C+E M$} & C. coli & $0 / 7$ & $0 / 54$ & $0 / 6$ & $0 / 12$ \\
\hline & C. jejuni & 0/92 & $2 / 90(2.2)$ & $0 / 15$ & $3 / 30(10.0)$ \\
\hline \multirow[t]{2}{*}{$\mathrm{TC}+\mathrm{AZM}$} & C. coli & $0 / 7$ & $0 / 54$ & $0 / 6$ & $0 / 12$ \\
\hline & C. jejuni & 0/92 & $0 / 90$ & $0 / 15$ & $3 / 30(10.0)$ \\
\hline \multirow[t]{2}{*}{$\mathrm{Cl}+\mathrm{EM}$} & C. coli & $0 / 7$ & 2/54 (3.7) & $1 / 6(16.7)$ & $0 / 12$ \\
\hline & C. jejuni & 0/92 & 3/90 (3.3) & $0 / 15(0)$ & $3 / 30(10.0)$ \\
\hline \multirow[t]{2}{*}{$\mathrm{Cl}+\mathrm{AZM}$} & C. coli & $0 / 7$ & $0 / 54$ & $1 / 6(16.7)$ & $0 / 12$ \\
\hline & C. jejuni & 0/92 & $0 / 90$ & $1 / 15(6.7)$ & $3 / 30(10.0)$ \\
\hline \multirow[t]{2}{*}{$\mathrm{Cl}+\mathrm{AZM}+\mathrm{EM}$} & C. coli & $0 / 7$ & $0 / 54$ & $1 / 6(16.7)$ & $0 / 12$ \\
\hline & C. jejuni & 0/92 & 0/90 & $0 / 15$ & $2 / 30(6.7)$ \\
\hline \multirow[t]{2}{*}{$C l+T C+A Z M$} & C. coli & $0 / 7$ & $0 / 54$ & $0 / 6$ & $0 / 12$ \\
\hline & C. jejuni & 0/92 & $0 / 90$ & $0 / 15$ & $3 / 30(10.0)$ \\
\hline \multirow[t]{2}{*}{$\mathrm{Cl}+\mathrm{TC}+\mathrm{EM}$} & C. coli & $0 / 7$ & $1 / 54(1.9)$ & $0 / 6$ & $0 / 12$ \\
\hline & C. jejuni & 0/92 & $2 / 90(2.2)$ & $0 / 15$ & $3 / 30(10.0)$ \\
\hline \multirow[t]{2}{*}{$T C+A Z M+E M$} & C. coli & $0 / 7$ & $0 / 54$ & $0 / 6$ & $0 / 12$ \\
\hline & C. jejuni & 0/92 & $0 / 90$ & $0 / 15$ & $2 / 30(6.7)$ \\
\hline \multirow[t]{2}{*}{$\mathrm{TC}+\mathrm{Cl}+\mathrm{AZM}+\mathrm{EM}$} & C. coli & $0 / 7$ & $0 / 54$ & $0 / 6$ & $0 / 12$ \\
\hline & C. jejuni & 0/92 & 0/90 & $0 / 15$ & $1 / 30(3.3)$ \\
\hline
\end{tabular}


suburban area agents that could play a role in campylobacteriosis in children. Faeces of birds, stray dogs, cats and other wild animals inhabiting many playgrounds and parks in urban and suburban areas can be the environmental source of campylobacteriosis for children [16, 29]. Due to the fact ornamental lakes and fountains are contaminated with the animals' faeces they become a potential source of Campylobacter to children.

In the study, Campylobacter was isolated from 99 (9.6\%) samples from children with diarrhoea. C. jejuni (8.9\%) was isolated more often than C. coli $(0.7 \%)$. Our results are similar to those obtained in Warsaw (Poland) by Rozynek et al. [15]. In England and Wales, as well as in other industrialised countries, $C$. jejuni was present in $5-16 \%$ of children with diarrhoea, while frequency of these bacteria in healthy children was from 0 to $1.5 \%$ $[28,30,31]$.

Handling and consumption of chicken meat were described as the main risk factors for human campylobacteriosis in many of the analytical epidemiological studies [32-34]. Infants and young children could become infected with Campylobacter by touching contaminated poultry meat or contaminated equipment. Contaminated hands of caretakers can be also a source of infection [35]. In this study, Campylobacter was detected in $33.3 \%$ of tested chicken meat samples, thus confirming that the risk of infections is high. In our study conducted in the same area during 2009-2013, the occurrence of Campylobacter in retail poultry meat was higher $(41.6 \%)$ and exhibited a decreasing temporal trend from $60.2 \%$ in 2009 to $32.0 \%$ in 2013 [23]. The decrease of Campylobacter spp. level in poultry carcasses from $70 \%$ in 2009 to $39 \%$ in 2013 was also observed and presented by Department of Hygiene of Food of Animal Origin National Veterinary Research Institute in Pulawy [36]. This decreasing trend in Poland could be considered to be a result of the implementation of the European Union standards on how to produce poultry meat with a very low contamination level of Campylobacter.

Sporadic campylobacteriosis are connected with contact with pets [37-39]. Fullerton et al. [35] suggest that infants older than 6 months are physically closer to pets and their equipment, which increases a risk of transmission. Frequency of isolation of Campylobacter spp. in dogs varied from 17\% (Brazil) to $76.2 \%$ (Denmark), while in cats isolation values ranged from $8 \%$ in Brazil to $47.8 \%$ in Germany [40-42]. In our study the prevalence of Campylobacter isolates in dogs was that of $6.2 \%$ and it was lower than that in other studies as well as $10.5 \%$ of the samples obtained from cats tested positive for Campylobacter spp. According to TNS Polska (Public Opinion Research Centre), in 2014 in Poland (population: 38.5 million) there were about 8 million dogs and 6 million cats, with $48 \%$ of the country's citizens owning at least one dog or cat $[43,44]$. This interaction between pets and children raises concerns regarding potential zoonotic risks.

The prevalence of Campylobacter in surface water varies from 0 to $87.5 \%$ as reported $[45,46]$. Over the course of our 3-years study, contaminated surface water was a potential reservoir of Campylobacter; with $16.8 \%$ of total and $17.5 \%$ of river water samples testing positive for Campylobacter. Campylobacter has not been detected in freshwater beach samples, thus indicating that the risk of outbreaks during swimming in the Bydgoszcz region is low. By contrast, $20.0 \%$ of water samples taken from fountains and ornamental lakes contained Campylobacter. These facilities are very popular in public parks and town centres. When it is hot children like to play in the fountain water that may be contaminated by enteric pathogens. Accidental defecation and rinsing of contaminated human bodies increase the level of contamination of recreational water. Fountains often serve as drinking bowls for birds or stray dogs and cats, and may contribute to the transmission of pathogenic species of microorganisms [27]. Outbreaks of norovirus [47], Shigella sonnei [48], legionnaires' disease [49] associated with a recreational spray or fountain water were reported in some countries but hard evidence studies on the role of decorative pools and fountains in Campylobacter pathogenesis are still necessary.

A great number of environmental and animal reservoirs makes the epidemiology of Campylobacter infection very complicated. A risk factor of campylobacteriosis connected with food $[4,50]$ and faecal material from livestock $[38,51]$ has been extensively studied. Urban wild birds such as ducks, goose, starlings [52, 53], as well as birds inhabiting human settlements, such as white stork [54], contribute to enormous faecal contamination of the environment and need to be treated as an important source of campylobacteriosis for humans and farm animals.

The same Campylobacter isolates in children stool samples, surface water and poultry were reported in a previous study conducted in the Bydgoszcz region [55]. Our present study showed lower prevalence of C. coli in all sources tested (7, 37.5 and 32\% of children, chicken, and water isolates, respectively) than in the study during 2006-2008 (42, 75, and 78\%, respectively). Despite a common geographic location these studies were different over time. However, it should be noted that places where samples for research were gathered were different as well. In our previous study chicken isolates were obtained in one poultry slaughterhouse located in the rural area and water samples were collected from rivers and ponds in both urban and rural areas. In our study, poultry meat samples were taken from supermarkets and retail butcher shops, which may indicate different sources of origin of the poultry. Environmental water samples were obtained 
from different sites located within urban and suburban areas and the samples were taken from rivers, ponds, as well as from ornamental lakes and city fountains that had not been tested before. It may prove circulation of Campylobacter spp. between poultry, humans, surface water and pets in the area. Further studies on this subject with the use of molecular typing methods need to be conducted to ascertain the transmission of Campylobacter within the environment.

In recent years antimicrobial resistance in foodborne pathogens, including Campylobacter, is one of essential public health problems $[7,13,56]$. Antibiotics used for growth-promotion in rearing of animals are used at low levels but for a long period of time; consequently, the emergency of resistant bacteria is significant. Due to veterinary applications of enrofloxacin and other quinolones the emergency of ciprofloxacin resistance of Campylobacter isolated from poultry and human is observed [13,57]. The research confirmed a high level of ciprofloxacin resistance (>50\%) among all Campylobacter isolates, especially in C. jejuni isolated from $85 \%$ ponds and $80 \%$ dogs and in C. coli isolated from children and poultry meat (71.4 and $74.1 \%$, respectively). High resistance to fluoroquinolones and quinolones make these agents useless in therapy of children and adults Campylobacter infections. Reports from Poland $[15,58]$ and other countries $[13,59,60]$ confirm this statement. The high rate of resistance to ciprofloxacin in isolates obtained from children may result from a transmission of animals (including poultry and pets), since quinolones are used only occasionally in paediatric patients, mainly in the treatment of cystic fibrosis. Furthermore, tetracyclines are used in veterinary medicine in Poland, and high resistance to them was observed in Campylobacter spp. of poultry, cattle and pigs origin in our country $[7,15,61]$. In the study, the overall tetracycline resistance observed did exceed $30 \%$, and there were no significant differences in tetracycline resistance between all isolates.

In spite of reports from some parts of the world reporting a slowly increasing resistance rate to macrolides in Campylobacter, these antibiotics are the optimal drugs for treatment of campylobacteriosis especially in paediatric patients $[7,12,62]$. In this study, all children isolates were found to be susceptible to azithromycin and erythromycin, but resistance to these drugs was detected in some Campylobacter isolates from cats, ponds and fountains. Among Campylobacter isolated from poultry meat a low rate of resistance to erythromycin in general was observed (C. coli, 3.7\% and C. jejuni, 4.4\%) and it was similar to that reported in poultry isolates by Rozynek [58]. Resistant mutants develop slowly during antibiotic treatment. Subtherapeutic doses of tylosin given continuously in food exert a more significant influence on development of macrolide-resistant Campylobacter then therapeutic use of this antibiotic in chicken. Ladely et al. [63] found that long period of exposure to macrolides leads to macrolide resistance in Campylobacter. The studies of Hao et al. [64] compared the fitness of erythromycin-resistant and susceptible Campylobacter. The fitness reduction observed in resistant Campylobacter may cause lower frequency of macrolide resistance in clinical isolates. The continuous use of macrolides in food-producing animals at subtherapeutic concentrations is a major risk factor influencing the emergence of erythromycin resistance of Campylobacter isolated from animals and environmental sources $[63,65,66]$.

The most frequent resistance pattern observed in this study was the lack of susceptibility to a single agent, which was characteristic for all isolates. Double resistance to ciprofloxacin and tetracycline was detected most frequently both in children $(28.6 \%$ C. coli and $36.9 \%$ C.jejuni), and in pet $(33.3,22.6 \%)$ isolates, and this percentage was higher than that reported by other authors $[15,67]$. It should also be emphasised that one C. jejuni isolate from a fountain was simultaneously resistant to erythromycin, azithromycin, tetracycline and ciprofloxacin. A water sample was taken on a warm sunny day in May from the ornamental fountain located in the City Park near a children's playground. Water was sprayed $1.2 \mathrm{~m}$ into the air and fell down into the fountain basin with a concrete bottom and a water surface area of $\sim 40 \mathrm{~m}^{2}$. The fountain had a closed system in which recirculating water could stagnate, whereas the total water replacement took place only once or twice during their exploitation. The fountain was not equipped with disinfecting or filtering devices. This shows the necessity of regular control not only of the design but also of operation of water facilities used for recreation.

Antimicrobials used in the rearing of food-producing animals cause strong selection of bacteria including pathogenic ones. Genotypes resistant to antimicrobial compounds can spread from farms into the environment. The natural reservoirs such as surface water, pets and wild birds are under threat of contamination with these bacteria.

\section{Conclusions}

This is the first study on urban ornamental lakes and fountains as potential reservoirs of Campylobacter and one of few that provide data on the antimicrobial resistance of Campylobacter isolated from surface water. The results of our study show that fountains can be a direct source of children campylobacteriosis but also a source of crosscontamination of other environments with multidrugresistant Campylobacter. Consequently, regular monitoring of water facilities used for recreation is necessary. This study suggests that surface water, poultry meat and pets can be potential sources of Campylobacter to children. 
High resistance among the isolates to some antimicrobials may lead to increasing numbers of difficult-to-treat campylobacteriosis in children. Therefore, constant monitoring of resistance is required in both children and environmental Campylobacter isolates. In order to improve the understanding of the complex epidemiology of Campylobacter infections further studies should be conducted on larger population and on various sampling groups, with the use of molecular techniques.

\section{Acknowledgements}

None.

\section{Funding}

This work was supported by scientific grant from the National Science Centre in Poland No. NN 404 272,540 by BS.

\section{Availability of data and materials}

All data and materials are available in the Department of Hygiene, Epidemiology and Ergonomics, Nicolaus Copernicus University in Torun, Collegium Medicum in Bydgoszcz 9 Skłodowska-Curie Str., PL 85-094 Bydgoszcz, Poland.

\section{Authors' contributions}

BS conceived the study, designed and coordinated of the study, participated in material and data collection, analysed the date, wrote the manuscript. MA participated in designing the study, participated in material and data collection and assisted in drafting the manuscript. DŚ was responsible for the isolation and identification of the isolates. JJK participated in acquisition of funding and critically revised the manuscript. All authors read and approved the final manuscript

\section{Competing interests}

The authors declare that they have no competing interests.

\section{Consent for publication}

Not applicable.

\section{Ethics approval and consent to participate}

Ethical approval for the study was obtained from the ethical committee of the Collegium Medicum in Bydgoszcz, Nicolaus Copernicus University in Torun, Poland (No.KB 400/2011). Written informed consent was obtained from the caregiver of each enrolled child.

The faecal and cloacal samples from the pets were collected by a veterinarian as part of his work. According to Polish law (the act on experiments on animals of 21 January 2005), permission from the ethics commission is not required for this type of sample collection.

\section{Publisher's Note}

Springer Nature remains neutral with regard to jurisdictional claims in published maps and institutional affiliations.

Received: 19 November 2016 Accepted: 23 March 2017 Published online: 04 April 2017

References

1. EFSA (European Food Safety Authority) and ECDC (European Centre for Disease Prevention and Control). The European Union summary report on trends and sources of zoonoses, zoonotic agents and food-borne outbreaks in 2014. EFSA J. 2015;13(12):4329. doi:10.2903/j.efsa.2015.4329.191 pp

2. Silva J, Leite D, Fernandes M, Mena C, Gibbs PA, Teixeira P. Campylobacter spp. as a foodborne pathogen: a review. Front Microbiol. 2011;2:200

3. Humphrey T, O'Brien S, Madsen M. Campylobacters as zoonotic pathogens: A food production perspective. Int J Food Microbiol. 2007;117:237-57.

4. Friedman CR, Hoekstra RM, Samuel M, Marcus R, Bender J, Shiferaw B, et al. Risk factors for sporadic Campylobacter infection in the United States: A case-control study in FoodNet sites. Clin Infect Dis. 2004;38(Suppl 3):285-96.
5. Kaakoush NO, Castaño-Rodríguez N, Mitchell HM, Man SM. Global epidemiology of Campylobacter infection. Clin Microbiol Rev. 2015;28(3): 687-720. doi:10.1128/CMR.00006-15.

6. Smith-Palmer, A. Private water supplies as a risk factor for Campylobacter infection in Aberdeen City and Aberdeenshire. Health Protection Scotland; 2011

7. Wieczorek K, Osek J. Antimicrobial Resistance Mechanisms among Campylobacter. Biomed Res Int 2013. doi:10.1155/2013/340605.

8. Nyati KK, Nyati R. Role of Campylobacter jejuni Infection in the Pathogenesis of Guillain-Barré Syndrome: An Update. Biomed Res Int. 2013; doi:10.1155/2013/852195.

9. Allos BM. Campylobacter jejuni infections: Update on emerging issues and trends. Clin Infect Dis. 2001;32:1201-6.

10. Blaser B, Engberg J. Clinical aspects of Campylobacter jejuni and Campylobacter coli infections. In: Nachamkin I, Szymanski CM, Blaser MJ, editors. Campylobacter. Washington DC: American Society for Microbiology; 2008. p. 99-121.

11. Wimalarathna HM, Richardson JF, Lawson AJ, Elson R, Meldrum R, Little CL, et al. Widespread acquisition of antimicrobial resistance among Campylobacter isolates from UK retail poultry and evidence for clonal expansion of resistant lineages. BMC Microbiol. 2013. doi: 10.1186/1471-2180-13-160.

12. Kurincic M, Botteldoorn N, Herman L, Smole Mozina S. Mechanisms of erythromycin resistance of Campylobacter spp. isolated from food, animals and humans. Int J Food Microbiol. 2007;120:186-90.

13. Gupta A, Nelson JN, Barrett TJ, Tauxe RV, Rossiter SP, Friedman CR, Joyce KW, the NARMS Working Group, et al. Antimicrobial resistance among Campylobacter strains, United States, 1997-2001. Emerg Infect Dis. 2004;10:1102-9.

14. Lindmark H, Harbom B, Thebo L, Andersson L, Hedin G, Osterman B, et al. Genetic characterization and antibiotic resistance of Campylobacter jejuni isolated from meats, water, and humans in Sweden. J Clin Microbiol. 2004; 42:700-6.

15. Rozynek E, Dzierzanowska-Fangrat K, Korsak D, Konieczny P, Wardak S, Szych J, Jarosz M, Dzierzanowska D. Comparison of antimicrobial resistance of Campylobacter jejuni and Campylobacter coli isolated from humans and chicken carcasses in Poland. J Food Prot. 2008;71:602-7.

16. Bronowski $C$, James $C E$, Winstanley $C$. Role of environmental survival in transmission of Campylobacter jejuni. FEMS Microbiol Lett. 2014;356(1):8-19. doi:10.1111/1574-6968.12488.

17. Hendriksen RS, Wagenaar J, Bergen MA. Global Salm-Surv. A global Salmonella surveillance and laboratory support project of the World Health Organization Level 2 training course: isolation of thermotolerant Campylobacter from faeces; identification of thermotolerant Campylobacter. 2003. Available at: http://www.antimicrobialresistance.dk/data/images/ campylobacter1_pdf.pdf. Accessed 23 June 2016.

18. ISO. Microbiology of Food and Animal Feeding Stuffs - Horizontal Method for Detection and Enumeration of Campylobacter spp. Part 1: Detection Method. Geneva: International Organization for Standardization. 2006. [ISO 10272-1:2006].

19. Health Protection Agency. Detection of Campylobacter species in water. National Standard Method.2007.W8 Issue 3. http://www.hpastandardmethods.org.uk/pdf_sops.as. Accessed 15 Nov 2009.

20. de Lamballerie X, Zandotti C, Vignoli C, Bollet C, de Micco P. A one- step microbial DNA extraction method using "Chelex 100" suitable for gene amplification. ResMicrobiol. 1992;143:785-90.

21. Linton D, Lawson AJ, Owen RJ, Stanley J. PCR detection, identification to species level, and fingerprinting of Campylobacter jejuni and Campylobacter coli direct from diarrheic samples. J Clin Microbiol. 1997;35:2568-72.

22. On ST, Jordan PJ. Evaluation of 11 PCR assays for species-level identification of Campylobacter jejuni and Campylobacter coli. J Clin Microbiol. 2003;41:330-6.

23. Andrzejewska M, Szczepańska B, Śpica D, Klawe JJ. Trends in the occurrence and characteristics of Campylobacter jejuni and Campylobacter coli isolates from poultry meat in Northern Poland. Food Control. 2015;51:190-4.

24. Lehtopolku M, Nakari U-M, Kotilainen P, Huovinen P, Siitonen A, Hakanen AJ. Antimicrobial susceptibilities of multidrug-resistant Campylobacter jejuni and C. coli strains: in vitro activities of 20 antimicrobial agents. Antimicrob Agents Chemother. 2010;54:1232-6. doi:10.1128/AAC.00898-09.

25. Clinical and Laboratory Standards Institute. Performance Standards for Antimicrobial Susceptibility Testing; Eighteenth Informational Supplement. CLSI document M100-S18. Wayne, PA: Clinical and Laboratory Standards Institute. 2008.

26. Schielke A, Rosner BM, Stark K. Epidemiology of campylobacteriosis in Germany - insights from 10 years of surveillance. BMC Infect Dis. 2014;14:30.

27. Nichols $\mathrm{G}$. Infection risks from water in natural and man-made environments. Euro Surveill. 2006:11(4). Available online: http://www. eurosurveillance.org/ViewArticle.aspx?Articleld=611. Accessed 23 June 2016. 
28. Nichols GL, Richardson JF, Sheppard SK, Lane C, Sarran C. Campylobacter epidemiology: a descriptive study reviewing 1 million cases in England and Wales between 1989 and 2011. BMJ Open. 2012;2(4):e001179. doi:10.1136/ bmjopen-2012-001179.

29. French NP, Midwinter A, Holland B, Collins-Emerson J, Pattison R, Colles F, Carter P. Molecular epidemiology of Campylobacter jejuni isolates from wild-bird fecal material in children's playgrounds. Appl Environ Microbiol. 2009;75:779-83.

30. Ruiz-Palacios GM. The health burden of Campylobacter infection and the impact of antimicrobial resistance: Playing chicken. Clin Infect Dis. 2007;44: 701-3.

31. Koehler KM, Lasky T, Fein SB, Delong SM, Hawkins MA, Rabatsky-Her T, et al. Population-based incidence of infection with selected bacterial enteric pathogens in children younger than five years of age, 1996-1998. Pediatr Infect Dis J. 2006;25:129-34.

32. Mellou K, Sourtzi P, Tsakris A, Saroglou G, Velonakis E. Risk factors for sporadic Campylobacter jejuni infections in children in a Greek region. Epidemiol Infect. 2010;138:1719-25.

33. Lopez GU, Kitajima M, Sherchan SP, Sexton JD, Sifuentes LY, Gerba CP, Reynolds KA. Impact of disinfectant wipes on the risk of Campylobacter jejuni infection during raw chicken preparation in domestic kitchens. J Appl Microbiol. 2015;119:245-52. doi:10.1111/jam.12834.

34. Mughini Gras L, Smid JH, Wagenaar JA, de Boer AG, Havelaar AH, et al. Risk Factors for Campylobacteriosis of Chicken, Ruminant, and Environmenta Origin: A Combined Case-Control and Source Attribution Analysis. PLoS One. 2012;7(8):e42599. doi:10.1371/journal.pone.0042599.

35. Fullerton KE, Ingram LA, Jones TF, Anderson BJ, McCarthy PV, Hurd S, et al. Sporadic Campylobacter infection in infants: a population-based surveillance case-control study. Pediatr Infect Dis J. 2007;26:19-24.

36. Wieczorek K, Osek J. Antybiotykooporność Campylobacter - sytuacja epidemiologiczna i zagrożenie dla konsumentów. In: Szteyn J, Wysok B, Wojtacka J, Gomolka-Pawlicka M, Wiszniewska-Laszczych A, editors. Kamylobakteriozy stan obecny i perspektywy zmian. Olsztyn: Monografia; 2015. p. 73-87.

37. Neimann J, Engberg J, Molbak K, Wegener HC. A case-control study of risk factors for sporadic Campylobacter infections in Denmark. Epidemiol Infect. 2003;130:353-66

38. Mohan V. Faeco-prevalence of Campylobacter jejuni in urban wild birds and pets in New Zealand. BMC Res Notes. 2015;8:1.

39. Carrique-Mas J, Andersson Y, Hjertqvist M, Svensson A, Torner A, Giesecke J. Risk factors for domestic sporadic campylobacteriosis among young children in Sweden. Scand J Infect Dis. 2005;37:101-10.

40. Moser I, Rieksneuwohner B, Lentzsch P, Schwerk P, Wieler LH. Genomic heterogeneity and O-antigenic diversity of Campylobacter upsaliensis and Campylobacter helveticus strains isolated from dogs and cats in Germany. J Clin Microbiol. 2001;39:2548-57.

41. Aquino MH, Pacheco AP, Ferreira MC, Tibana A. Frequency of isolation and identification of thermophilic Campylobacters from animals in Brazil. Vet J. 2002:164:159-61.

42. Hald B, Pedersen K, Wainø M, Jørgensen JC, Madsen M. Longitudinal study of the excretion patterns of thermophilic Campylobacter spp. in young pet dogs in Denmark. J Clin Microbiol. 2004;42:2003-12.

43. Magazyn Handel. Euromonitor: Rośnie rynek karmy dla zwierząt w Polsce. Mrozowska I. 2014, http://handelextra.pl/artykuly/179043,euromonitorrosnie-rynek-karmy-dla-zwierzat-w-polsce. Accessed 19 Sept 2015.

44. TNS Polska. Zwierzęta w polskich domach. 2014. http://www.tnsglobal.pl/ archiwumraportow/files/2014/11/K.073_Zwierz\%C4\%99ta_w_polskich domach_O10a-14.pdf. Accessed 23 June 2016.

45. Close M, Dann R, Ball A, Pirie R, Savill M, Smith Z. Microbial ground water quality and its health implications for a border-strip irrigated dairy farm catchment, South Island. N Z J Water Health. 2008;6(1):83-98.

46. Moore JE, Caldwell PS, Millar BC, Murphy PG. Occurrence of Campylobacter spp. in water in Northern Ireland: implications for public health. Ulster Med J. 2001;70:102-7.

47. Hoebe CJ, Vennema H, Husman AM, van Duynhoven YT. Norovirus outbreak among primary schoolchildren who had played in a recreational water fountain. J Infect Dis. 2004;189(4):699-705.

48. Fleming CA, Caron D, Gunn JE, Horine MS, Matyas BT, Barry MA. An outbreak of Shigella sonnei associated with a recreational spray fountain. Am J Public Health. 2000;90(10):1641-2.

49. Hlady WG, Mullen RC, Mintz CS, Shelton BG, Hopkins RS, Daikos GL. Outbreak of Legionnaire's disease linked to a decorative fountain by molecular epidemiology. Am J Epidemiol. 1993;138(8):555-62.
50. Siemer BL, Nielsen EM, On SLW. Identification and molecular epidemiology of Campylobacter coli isolates from human gastroenteritis, food, and animal sources by amplified fragment length polymorphism analysis and penner serotyping. Appl Environ Microbiol. 2005;71:1953-8. doi:10.1128/AEM.71.4. 1953-1958.2005

51. Mullner P, Collins-Emerson JM, Midwinter AC, Carter P, Spencer SEF, van der Logt $P$, et al. Molecular epidemiology of Campylobacter jejuni in a geographically isolated country with a uniquely structured poultry industry. Appl Environ Microbiol. 2010;76:2145-54.

52. Colles FM, Dingle KE, Cody AJ, Maiden MCJ. Comparison of Campylobacter populations in wild geese with those in starlings and free-range poultry on the same farm. Appl Environ Microbiol. 2008;74:3583-90.

53. Colles FM, Ali JS, Sheppard SK, McCarthy ND, Maiden MCJ. Campylobacter populations in wild and domesticated Mallard ducks (Anas platyrhynchos). Environ Microbiol Rep. 2011:3:574-80.

54. Szczepanska B, Kamiński P, Andrzejewska M, Spica D, Kartanas E, Ulrich W, Jerzak L, Kasprzak M, Bochenski M, Klawe JJ. Prevalence, virulence, and antimicrobial resistance of Campylobacter jejuni and Campylobacter coli in white stork Ciconia ciconia in Poland. Foodborne Pathog Dis. 2015;12(1):24-31. doi:10.1089/fpd. 2014.1793.

55. Rozynek E, Antos-Bielska M, Dzierzanowska-Fangrat K, Szczepanska B, Trafny EA. Genetic similarity of Campylobacter isolates in humans, food, and water sources in central Poland. Foodborne Pathog Dis. 2010;7:597-600.

56. EFSA, European Food Safety Authority. The European Union Summary Report on antimicrobial resistance in zoonotic and indicator bacteria from humans, animals and food in 2012. EFSA J. 2014;12:3590.

57. Engberg J, Neimann J, Nielsen EM, Aarestrup FM, Fussing FM. Quinolone-resistant Campylobacter infections in Denmark: risk factors and clinical consequences. Emerg Infect Dis. 2004;10:1056-63.

58. Rozynek E, Dzierzanowska-Fangrat K, Szczepanska B, Wardak S, Szych J, Konieczny P, Albrecht P, Dzierzanowska D. Trends in antimicrobial susceptibility of Campylobacter isolates in Poland (2000-2007). Pol J Microbiol. 2007;58:111-5.

59. Quinn T, Bolla JM, Pages JM, Fanning S. Antibiotic- resistant Campylobacter: Could efflux pump inhibitors control infection? J Antimicrob Chemother. 2007:59:1230-6.

60. Han X, Zhu D, Lai H, Zeng H, Zhou K, Zou L, Wu C. Prevalence, antimicrobial resistance profiling and genetic diversity of Campylobacter jejuni and Campylobacter coli isolated from broilers at slaughter in China. Food Control. 2016:69:160-70.

61. Wieczorek K, Osek J. Characteristics and antimicrobial resistance of Campylobacter isolated from pig and cattle carcasses in Poland. Polish J Vet Sci. 2013;16(3):501-8.

62. Vlieghe ER, Jacobs JA, Van Esbroeck M, Koole O, Van Gompel A. Trends of norfloxacin and erythromycin resistance of Campylobacter jejuni/Campylobacter coli isolates recovered from international travelers, 1994 to 2006. J. Travel Med. 2008;15(6):419-25.

63. Ladely SR, Harrison MA, Fedorka-Cray PJ, Berrang ME, Englen MD, Mainersman RJ. Development of macrolide-resistant Campylobacter in broilers administered subtherapeutic or therapeutic concentrations of tylosin. J Food Prot. 2007:70(8):1945-51.

64. Hao H, Dai M, Wang Y, Peng D, Liu Z, Yuan Z. 23 S rRNA mutation A2074C conferring high-level macrolide resistance and fitness cost in Campylobacter jejuni. Microb Drug Resist. 2009;15(4):239-44.

65. Rozynek E, Mackiw E, Kaminska W, Tomczuk K, Antos-Bielska M, DzierzanowskaFangrat K, Korsak D. Emergence of Macrolide-Resistant Campylobacter Strains in Chicken Meat in Poland and the Resistance Mechanisms Involved. Foodborne Pathog Dis. 2013;10(7):655-60. doi:10.1089/fpd.2012.1333.

66. Gibreel A, Taylor DE. Macrolide resistance in Campylobacter jejuni and Campylobacter coli. J Antimicrob Chemother. 2006:58:243-55.

67. Wieczorek K, Szewczyk R, Osek J. Prevalence, antimicrobial resistance, and molecular characterization of Campylobacter jejuni and C. coli isolated from retail raw meat in Poland. Veterinarni Medicina. 2012;57:293-9. 